\title{
The Interaction Effect of Financial Innovation and the Transmission Channels on Money Demand in Uganda
}

\author{
John Bosco Nnyanzi ${ }^{1}$ \\ ${ }^{1}$ Department of Economic Theory and Analysis, Makerere University, Kampala, Uganda \\ Correspondence: John Bosco Nnyanzi, Department of Economic Theory and Analysis, Makerere University, \\ Kampala, Uganda. E-mail: jbnnyanzi@yahoo.com
}

Received: August 14, 2018

Accepted: August 27, 2018

Online Published: November 5, 2018

doi:10.5539/ijef.v10n12p1

URL: https://doi.org/10.5539/ijef.v10n12p1

\begin{abstract}
The current study set out to examine the direct as well as the indirect effect of technological advances and diversification of the financial sector on money demand in Uganda using annual data from 1986 to 2017. The results derived on the basis of the ARDL framework provide evidence in confirmation of the significant role played by financial innovation in the demand for real narrow money balances both directly and indirectly via the real income as well as the inflation rate channels in the shortrun and longrun. The association appears to increase (decrease) once inflation (real income) decreases (increases). On the contrary, we find no evidence that the exchange rate and the interest rate channels matter in the financial-innovation-money-demand linkage although their independent effect is significantly indismissible. Surprisingly, besides the exchange rate and inflation rate, data does not allow conclusion of any significant role of financial innovation in real broad money balances. Finally, the money demand function is found stable over the study period. Overall, supportive policies that are pro-advancement in the creation and popularizing of the new financial instruments as well as new financial technologies, institutions and markets are strongly recommended for purposes of enhancing pro-growth financial innovations. Policy makers ought to give more attention to the income and inflation rate transmission channels if financial innovations are to be a benefit rather than a risk to money demand stability. The adoption of the inflation lite monetary framework was therefore a right step in the right direction.
\end{abstract}

Keywords: money, innovation, Uganda, ARDL

\section{Introduction}

The significance of a properly defined demand for money to the application of monetary policy has attracted notable attention in both developed and developing countries. The rationale for the renewed focus of the subject lies in both the persistent contradictions regarding the effects of the macroeconomic drivers of money demand and in the observed repercussions of money demand instability that have led to the abandonment of one framework to another. On the latter for example, evidence from the industrial and emerging economies already suggest that since the early 1990s, the money-targeting models had to be replaced by variants of inflation-targeting frameworks (Freedman \& Laxton, 2009). The underlying theoretical argument is that stable money demand is pivotal for conducting effective monetary policy as well as making it possible to forecast the impact of the latter on key macroeconomic variables (Cziraky \& Gillman, 2006). Recent literature suggests the inclusion of financial innovations, that have arisen from financial and monetary reforms and developments in financial systems, in money demand models in order to fully account for 'missing money' (Arrau \& Gregorio, 1991). There are concerns however that the expansion of financial instruments and innovations would undermine financial sector stability and eventually alter the landscape for the conduct of monetary policy. Already an empirical study by Dunne and Kasekende (2016) contends that financial innovation is likely to be one of the main reasons for the observed instability in the money demand partly because it is a shifter in the money demand function. By implication, the exclusion of financial innovation in the money demand function could lead to misspecification of the money demand. The possibility of the positive role of financial innovation in stabilizing money demand might however be indismissible although this may nevertheless depend on whether it reduces costs and risks or provide an improved service that meets the particular needs of the participants in the financial system (Solans, 2003). A clear understanding of the channels through which financial innovation would affect money demand is therefore crucial in determining the way forward. The current paper aims at providing a 
quantitative analysis of these channels.

Empirical literature is not in short of studies on the determinants of money demand. However, a limited number consider financial innovation in their analysis, with a majority focusing on advanced and transitional countries (e.g. Attanasio et al., 2002; Alvarez \& Lippi, 2009; and, Nagayasu, 2012), albeit with mixed findings. The developing world and Uganda in particular appear to have been ignored in the debate. Exceptions in the recent literature include inter alia, Nampewo and Opolot (2016) and, Dunne and Kasekende (2016). We contribute to the debate by examining the interactive role of financial innovation with the traditional money demand drivers, in order to quantitatively capture the channels via which the former affects real money balances in Uganda. The rationale for this approach hinges on the need for well-guided policies to enhance financial innovations via proper channels as a means of enhancing economic growth.

According to Mwega (2011), Uganda, like her neighbors particularly Kenya, Tanzania and Rwanda, has witnessed tremendous reforms in the financial and banking sector, which appear to have inevitably improved the sophistication of the financial systems. Some of the financial innovations that now characterize the financial sector development include inter alia, the introduction of automated teller machines (ATMs), the expansion of credit card and debit card usage, development of electronic banking products, mobile money services and agent banking. The advantages that accrue from such developments are not limited to ease of exchanges of goods and services, the promotion of savings, and the widening the availability of credit but extend into facilitating a refinance of obligations, allowing for better allocation of risk, and, matching the supply of risk instruments to the demand of investors willing to bear it. Additional benefits such as the lowering of the cost of capital, promoting greater efficiency, and facilitating the smoothing of consumption and investment decisions with considerable benefits for households and corporations need not to be underestimated. In Uganda, for example, EPRC (2013) reports that the share of the adult population that accesses financial services through the informal sources increased from 60 percent in 2009 to 75 percent in 2013. Moreover, as the new products contribute to the deepening of financial markets, financial innovation, in turn, entails fostering economic development just as it could help to moderate business cycle fluctuations. This is not to say that all is well with financial innovation. A detrimental effect of the same would perhaps originate from being a source of systemic risk when financial products expand rapidly in a buoyant economic environment, and investors in return tend to underestimate the risks that only occur in periods of economic stress. The implications of financial innovations on the stability of both financial indicators and monetary aggregates have thus been raised as a basis for renewed concern by the monetary authorities. Several studies have consequently examined the issue of money demand stability with focus on financial innovations, albeit with mixed results. Recent examples include Suliman and Dafaalla (2011), Bahmani-Oskooee and Gelan (2009), Kiptui (2014), Hamori (2008) and Salisu et al. (2013) who document stable money demand. On the other hand, the likes of Sichei and Kamau (2012), Nyamongo and Ndirangu (2013), Muhd and Majid (2004), Sriram (2009) and Kararach (2002) find money demand unstable, just as Bahmani-Oskooee and Bohl (2000), fail to find evidence of a stable money demand. A proper explanation for the mixed findings appears still elusive and hence the need for further investigation.

The current paper specifically examines two policy questions: First, we investigate the direct role of financial innovations in the demand for real money demand measured as real narrow money, M1, and then as real broad money, M2. Unlike Nampewo and Opolot (2016), the focus of the current paper is on real money demand rather than velocity of money. Note that the first measure of narrow money balances is dominant in developing countries (as in Mark \& Sul, 2003; Iyoboyi \& Pedro, 2016; Rao \& Kumar, 2009; and Salisu et al., 2013), justified by the argument that it would give good insights about a country like Uganda where alot of people do not have bank accounts, and the few hardly save because of the highly subsistence lifestyles and the high marginal propensity to consume. The selection of real broad money on the other hand is is based on its use in literature as an alternative or as a compliment to M1. Several authors such as Hamori et al. (2008), Dunne and Kasekende (2016) have employed both M1 and M2 while Salisu et al. (2013) only considered M1. The second objective and a nuance of our paper, is that we analyse the interactive role of the financial innovation with real income, interest rate spread, inflation rate and the exchange rate. In essence, the four possible channels through which financial innovation can have an effect on monetary policy are examined: the real income channel, the interest rate channel that alters the cost of finance, the inflation rate channel, and the exchange rate channel. Ho (2006) asserts that through such transmission mechanism, derivatives instruments can be employed to reduce the impact of nominal interest rate fluctuations. If prices are sticky and inflation subdues, change in interest rates induced by central bank has the capacity to affect the cost of capital and the availability of loanable funds, say, by increasing the quantity of liquidity, or lower short-term interest rate to make shortterm funds less expensive. Relatedly, Misati et al. (2011) contend that financial innovation could weaken the interest rate channel and thus affect monetary policy. For 
example, it can allow consumers to change their portfolio allocation which could in turn affect the ability of the bank to lend, hence influencing the interest rates. Specifically, we argue that the role of financial innovation in determining money demand is dependent on the performance of the macroeconomic demand drivers. A clear understanding of the avenues via whch financial innovation affects money demand might be useful for bettering policy in the monetary arena.

Overall, the results from the current study suggest that financial innovation is significantly important for money demand and narrow money in particular. The real income and inflation rate channels appear crucial in this relationship both in the shortrun and longrun. The direct effect of exchange rate and inflation rate on real narrow money balances turns out to be negative but less significant in the latter case. The effect of real income however is positive and weakly significant in the shortrun but insignificant in the longrun as it happens to be the case with the interest rate spread. Similarly, we find the money demand function stable during the period under analysis. Surprisingly, we fail to find evidence of the influential role of financial innovation in real broad money demand, although the direct significant negative repurcusions of the exchange rate and inflation rate on the same are observed. The real income elasticity of money demand is positive but weakly significant for both the real narrow money and real broad money models albeit in the shortrun. These results have profound repurcussions for macroeconomic as well as monetary policy.

The rest of the paper is organized as follows: The next section provides an overview of literature while Sections 3 and 4 profile the methodology and results respectively. Finally in section 5, we present a summary conclusion.

\section{Overview of Literature}

\subsection{Theories of Money Demand in Summary}

Theories in regard to money demand have evolved over time. According to the classical school of thought, all prices and wages are perfectly flexible. The classical quantity theory of money, advanced by Fisher (1911) demonstrates that $M V=P T$, where $\mathrm{M}$ is the money supply, $V$ is the velocity of circulation i.e. the rate at which money changes hands in the society, $P$ is the Price level, and, $T$ is the rate of Transaction. Given the assumption that $V$ and $\mathrm{T}$ are constant, the price level $P$ varies directly with the amount of change in money supply i.e. $P=M V$. The major limitation of Fisher's equation however is that contrary to what the theory claims, income elasticity of demand for money may well be different from unity.

To correct for some of the anomalies of the classical theory, Keynes (1936) abandoned the view that velocity was constant and developed a theory of money demand that emphasised the importance of interest rates. Keynes hypothesized that the transactions demand for money is dependent on the level of income. In addition, he theorized that the precautionary motive also generates a demand for money by offering a contingency plan for impromptu outflows during unanticipated situations. In the latter motive, money serves as a medium of exchange, and by and large, it depends on the level of income as well. Finally, Keynes suggested the speculative motive he lebels "liquidity preference". Here persons can hold their wealth either in money or in bonds which by implication means that the price that people are enthusiastic to pay for the latter is much dependent on the rate of interest that they will earn on their bond portion of their portfolio. Consequently the money demand is expressed as $M^{d}=f(y, i)$, where demand for real money balances, $M^{d}$ is expressed as a function of real income, $y$ and interest rate, $i$. The main drawback of Keynes' speculative demand for money however is that it visualizes that people hold their assets in either all money or all bonds. In reality, financial wealth is held in a mixture of money and bonds. It is on this basis that the post Keynesian approaches to demand for money came to the fore. Among these is the Friedman's theory which is a restatement of the quantity theory of money and prices. To Friedman (1956), demand for real money balances is expressed as: $M^{d}=M^{d}\left(i, r D \frac{\Delta P}{P}, Y, W\right)$, where $M^{d}$ is money demand; $\Delta P$ is change in prices; $p$ is price level; $i$ is Interest rate; $Y$ is income; $W$ is Wealth; and, $D$ is deposit rate. In line with Ollama (2017), the inclination for the current paper in regard to defining a money demand function is nevertheless grounded in the post Keynesian theory.

\subsection{Empirical Literature}

In the empirical work, studies on the determinants of money demand are numerous, albeit with mixed findings. 
Here focus is on scholarly works that have included financial innovation in their analysis. A study by Al-Sowaidi and Darrat (2006) for example examines the effects of financial innovations in Bahrain, the UAE and Qatar on the long-run money demand. The results reveal that despite the fast pace of financial innovation experienced in the three countries there was no undue shifts in the equilibrium money demand whether measured as narrow or broad money stock. Hye (2014) later on investigates the relationship between M1 or M2 and financial innovation in Pakistan during the period of 1995-1 to 2007-12 using the robust time series techniques. One important finding similar to Al-Sowaidi and Darrat (2006) is that financial innovation is positively affecting the demand for money in the long run as well as in the short run but shortrun elasticity is more than the long run elasticity. Additionally, the results underscore a long run relationship between money demand, interest rate, economic activity, inflation, financial innovation and exchange rate.

Kovanen (2004) uses the Granger causality and VAR methodologies to analyze the drivers of currency demand and inflation dynamics in Zimbabwe. The coefficient on the financial innovation variable, measured as the ratio of broad money to currency in circulation, is found insignificant. A similar study done on Malawi, however reports a significant impact of financial innovation on the demand for money in the shortrun period (Lungu et al., 2012). In the same year, Sichei and Kamau (2012) carry out a related study on Kenya using Automated Teller Machines (ATMs) as proxy for financial innovation, but find no evidence of any significant impact of financial innovation on money demand. The results additionally indicated money demand instability in Kenya particularly after the year 2007.

On the other hand, an adverse significant finding between financial innovation and money demand can be traced in several studies inter alia Mannah-Blankson and Belyne (2014) and Hye (2009) that employ the ratio of broad money to narrow money to proxy financial innovation. Support for their findings can be found in a recent study by Dunne and Kasekende (2016), using estimation techniques based on panel data for 34 countries between 1980 and 2013 to investigate the effect of financial innovation on money demand in sub-Saharan Africa. The results therefrom show that there is an adverse linkage between financial innovation and money demand in both the long run and the short run regardless of whether the exchange rate is accounted for or not. However, as the authors admit, differences in the types of financial innovations across African countries suggest that there is need to use country case studies to investigate the effect of financial innovation on money demand rather than relying on grouped countries.

Nampewo and Opolot (2016) contributes to the ongoing debate by investigating the impact of financial innovations on the stability of money velocity using quarterly data for the period 2000-Q1 to 2013-Q4. Using the ARDL estimation framework, the authors find significant negative and positive effects of financial innovations, proxied by the ratio of currency in circulation to broad money, and ratio of time deposits to demand deposits, on the money velocity in the short and long-run, respectively. Specifically, the 91-day Treasury bill rates, inflation expectations and the exchange rate are each found to exhibit significant and positive longrun relationship with money velocity. In the analysis, money velocity is found stable in the longrun. We attempt to re-examine a similar issue but focusing on money demand rather than the money velocity since our objective is to find out the direct and indirect contribution of financial innovation on the demand for real money balances and not merely money velocity.

Overall, from the aforementioned literature reviewed, the findings arrived at appear mixed and inconclusive but underline the importance of including financial innovation in the money demand function. Most of the studies have focused on the direct relationship between financial innovations on money demand and ignored the indirect impact that yet appears theoretically plausible and beneficial for policy. We bridge this gap by presenting perhaps for the first time for the Ugandan case an interactive approach that takes into consideration the various transmission channels of money demand. The argument at hand is that the role of financial innovation in money demand is likely dependent on the performance of the traditional macroeconomic drivers commonly known to impact on real money balances.

\section{Model Specification, Estimation and Data}

\subsection{Model Specification}

Based on the traditional money demand theories as well as the modern micro-founded dynamic stochastic general equilibrium models, we assume that the desired level of nominal money demand depends on the price level, a transaction (or scaling) variable, and a vector of opportunity costs (e.g. Walsh, 2010):

$$
\left(M^{*} / P\right)=f\left(g d p, r_{i}\right)
$$

Where $M^{*}$ is nominal money demand, $P$ is the price level, $g d p$ is real income (the transaction variable), that 
proxies economic activity (Note 1), and $r_{i}$ are the elements of the vector of opportunity costs which possibly also includes interest rate or interest rate spread and the inflation rate. In this case our empirical standard specification of the money demand function, in line with Handa (2000) appears as below:

$$
\ln M^{d}=\beta_{0}+\beta_{1} \ln g d p_{t}+\beta_{2} r_{t}+\varepsilon_{t}
$$

where real money demand $\left(M^{*} / P\right)$ is denoted as $\ln M^{d}$. We obtain a new equation (3) after disaggregating $r_{i}$ into different forms, and, adding financial innovation and exchange rate to the equation (2). Note that the aim of including the exchange rate variable is to reflect the substitution effect of holding domestic and foreign assets in case of any exchange rate movement.

$$
\ln M_{t}^{d}=\beta_{0}+\beta_{1} \ln g d p_{t}+\beta_{2} i r s_{t}+\beta_{3} \ln e x c h r_{t}+\beta_{4} \ln f i_{t}+\varepsilon_{t}
$$

Where, $\varepsilon_{t}$ is the error term; exchr is nominal exchange rate, $f_{i}$ is financial innovation; irs is interest rate spread measured as $(d r-t b)$ i.e. the difference between the 91-day treasury bill rate, $t b$, and the deposit rate, $d r$. Assuming an equal elasticity (in absolute value) for the 91-day treasury bill rate (tb) and the time deposits, we consider interest rate spread since the share of interest bearing portion in broad money has increased in a number of countries pointing to the fact that money is affected by relative returns rather than the general level of interest rates. The difference is therefore the return on domestic monetary assets relative to domestic non-monetary financial assets, i.e. the incremental opportunity cost of holding domestic non-monetary financial assets relative to domestic interest bearing bank deposits (Nachega, 2001).

From equation (3), $\beta_{0}$ is the intercept term, while $\beta_{1}, \ldots, \beta_{4}$ are the slope coefficients of the explanatory variables. $\beta_{4}$ is the slope of interest which has been found to be either positive (e.g. Nampewo \& Opolot, 2016; Dunne \& Kasekende, 2016; Lippi \& Secchi, 2009; Attanasio et al., 2002) or negative (e.g. Hye, 2009; Mannah-Blankson \& Belyne, 2004). $\beta_{3}$ is the coefficient on the nominal exchange rate that can either take a positive value if the wealth effect is greater than the substitution effect (Dobson \& Ramlogan, 2001) or negative value if the reverse is the case (sriram, 1999). All variables enter the model in a logarithimic form.

As mentioned earlier, a unique contribution of our study is the analysis of the indirect effect of financial innovation on money demand. In order to capture this impact, we now introduce interaction terms in equation (3) resulting into equation (4):

$$
\begin{aligned}
\ln M_{t}^{d}= & \beta_{0}+\beta_{1} \ln g d p_{t}+\beta_{2} \ln i r s_{t}+\beta_{3} \ln \text { exch } r_{t}+\beta_{4} \ln f i_{t} \\
& +\beta_{5}\left(\ln g d p^{*} \ln f i\right)_{t}+\beta_{6}(\ln \text { irs } * \ln f i)_{t}+\beta_{7}(\ln \text { exchr } * \ln f i)_{t}+\varepsilon_{t}
\end{aligned}
$$

In equation (4), $\beta_{4}$ together with the interaction term coefficients, $\beta_{5}$ to $\beta_{7}$ constitute our focus. It should be noted that in estimating equation (4), interactions are included one at a time to avoid multicollinearity. We analyse the marginal effects considering each interation individually. For example, the marginal effect of real money demand with respect to financial innovation is given as:

$$
\frac{\partial \ln M_{t}^{d}}{\partial \ln f i}=\beta_{5}+b_{7} \overline{\operatorname{lnirs}}
$$

Here $\overline{\text { lnirs }}$ is the mean of the $\log$ of interest rate spread in the sample, as observed in Table 2 (Descriptive statistics). Intuitively, the argument follows that the direct impact of financial innovation on money demand is conditional on the performance of interest rate elasticity of demand. The rest of the interactions follow a similar analysis and interpretation as the interest rate channel in equation (5).

We estimate equation (4) for the overall sample period with the selected proxy of financial innovation, viz., M1/M2 (also adopted in Hye, 2009; Nampewo \& Opolot, 2016). The dependent variable is $M^{d}$ calculated as the ratio of either narrow money (M1) or broad money (M2) to consumer price index, where the latter is used for robustness purposes.

\subsection{Estimation Techniques}

The current study employs the Auto Distributed Lag (ARDL) bounds testing econometric methods engineered by Pesaran et al. (2001), to assess the long-run cointegrating relationship for money demand. Rewriting equation (3) as an ARDL model then appears as (Note 2):

$$
\begin{aligned}
\Delta M_{t}^{d}= & \lambda_{0}+\sum_{i=1}^{\kappa 1} \lambda_{i} \Delta \ln M_{t-i}^{d}+\sum_{i=1}^{\kappa 2} \beta_{i} \Delta \ln g d p_{t-i}+\sum_{i=1}^{\kappa 3} \phi_{i} \Delta \ln i r s+\sum_{i=1}^{\kappa 4} \psi_{i} \Delta \ln f i_{t-i} \\
& +\delta_{1} \ln M_{t-i}^{d}+\delta_{2} \ln g d p_{t-i}+\delta_{3} \ln i r s_{t-i}+\delta_{4} \ln f i_{t-i}+\varepsilon_{t}
\end{aligned}
$$

Where, $\Delta$ represents first differences; $\kappa$ is the number of non-deterministic regressors in long-run relationship. The strengths of the ARDL technique hinge on the fact that cointegration of nonstationary variables is equivalent 
to an error-correction (EC) process. Additionally, the ARDL model has a reparameterization in EC form (Engle and Granger, 1987; Hassler \& Wolters, 2006) that allows the testing of the existence of a long-run/cointegrating relationship. Under the approach, Pesaran et al. (2001) propose a bounds testing procedure to draw conclusive inference without requiring whether the variables are integrated of order zero, $\mathrm{I}(0)$ or one, $\mathrm{I}(1)$, respectively. This flexibility of the ARDL technique in terms of the order of integration, requiring no a priori testing for Stationarity is behind the motivation for adopting the technique. The Engle and Granger (1987) residual-based approach and the Johansen and Juselius (1990) lack these advantages. Likewise, we apply the bounds test used to determine the presence of cointegration among the variables basing on an F-statistic test (Pesaran et al., 2001). Specifically, we test the null hypothesis of no cointegration regardless of whether the regressors are I(1) or I( 0 ) against the alternative hypothesis of cointegration as below:

$$
\begin{aligned}
& H_{0}^{F}: \delta_{1}=\delta_{2}=\delta_{3}=\delta_{4}=0 \\
& H_{1}^{F}: \delta_{1} \neq 0, \delta_{2} \neq 0, \delta_{3} \neq 0, \delta_{4} \neq 0
\end{aligned}
$$

After computing the F-statistic for the joint null hypothesis, we then proceed to compare it to the critical values. If $H_{0}^{F}$ is rejected, we compute the t-statistic for the single null hypothes is $H_{0}^{t}: \alpha=0$ and compare it to the critical values. We re-estimate a parsimonious version of the ARDL/EC model. As asserted by Kripfganz and Schneider (2016), we can confirm the existence of a conditional long-run relationship if both $H_{0}^{F}$ and $H_{0}^{t}$ are rejected. Thus, cointegration exists if the null hypothesis is rejected, i.e. if the F-statistic is greater than the upper bound I(1) critical value. Otherwise if the null is not rejected, implying that the F-statistic is smaller than the critical values of the lower bound $\mathrm{I}(0)$, then co-integration does not exist. According to Pesaran et al. (2001), in case the F-test is between the $\mathrm{I}(0)$ and $\mathrm{I}(1)$ critical values, then the result is said to be inconclusive.

On the downside, however, prior to the cointegration test, the method requires a mandatory testing for stationarity. The above shortcomings are nevertheless taken care of under the ARDL approach. One disadvantage of the ARDL approach, however, is that it may not satisfactorily determine stability of the coefficients (Bahmani-Oskooee \& Gelan, 2009). Therefore, in addition to the ARDL framework, we also apply the cumulative sum of recursive residuals (CUSUM) and the cumulative sum of squares recursive residuals (CUSUMSQ) tests after cointegration to examine the stability of our model.

\subsection{Data}

To aid the estimation of money demand, we obtained annual data for the period 1986-2017. In line with previous works by inter alia Hamori et al. (2008) and Dunne and Kasekende (2016), we employ two dependent variables: The first dependent variable selected is real narrow money balances, computed by dividing narrow money, M1, by the consumer price index (CPI). The second dependent variable is real broad money computed by dividing broad money, M2, by CPI. The main explanatory variable is financial innovation commonly measured as a ratio of narrow money to broad money. Our choice of this measure is motivated by the fact that both M1 and M2 are readily available for Uganda but more so, as argued in Dunne and Kasekende (2016), as financial innovations grow, individuals tend to move away from more liquid assets, which are reflected in M1, to less liquid assets, which are reflected in M2. Table 1 reports the variables description, source of data and a priori expected signs. Similarly, Tables 2 and 3 present data descriptive statistics as well as the pairwise correlation matrix respectively. The evidence from the pairwise correlation matrix in Table 3 suggests low correlations between money demand as well as financial innovation index M1/M2 and other variables. By implication, multicollinearity does not appear to be a problem in the series.

It is important to examine the time-series properties of the individual variables before proceeding to the cointegration analysis and the estimation of long-run money demand. We employ the Augmented Dickey Fuller (ADF) and Phillips and Perron test (1988) on basis of our sample characteristics. Under the ADF unit root test. A computed absolute value of the t-statistic exceeding the ADF critical value implies a rejection of the null, in which case the time series is stationary, and vice versa. On the other hand, Phillips and Perron (PP), proposes a nonparametric method of controlling for serial correlation when testing for a unit root. The PP method corrects for any serial correlation and hetroskedasticity in the errors of the test regression by directly modifying the test statistics known as Phillips $Z \alpha$ and $Z t$ tests. The null hypothesis for either test is is that there is a unit root, implying non-stationarity of the time series, against the alternative of no unit root. We present the results in Tables 4 and 5 . It is clear from the table that all the variables except interest rate spread are not stationary in levels; they however become stationary in first difference $1 \%$ level of significance. In otherwords with the exception of interest rate spread, which is integrated of order zero, $I(0)$, all other variables are integrated of order one, $I(1)$. Since from the the ADF and PP tests none of the series we're working with are I(2), and we also have a mixture of $\mathrm{I}(0)$ and $\mathrm{I}(1)$, the best method is the ARDL approach. 
Table 1. Variable description, expected sign and source

\begin{tabular}{|c|c|}
\hline Variable & Description \\
\hline $\operatorname{lnm} d 1$ & Log of either real narrow money balances calculated first as the ratio narrow money-M1 (current LCU) to Consumer \\
\hline $\operatorname{lnm} d 2$ & $\begin{array}{l}\text { Price Index; or as a ratio of broad money to CPI. For robustness, we use the GDP deflator. Source: Bank of Uganda \& } \\
\text { World Bank. }\end{array}$ \\
\hline $\operatorname{lng} d p$ & $\begin{array}{l}\text { Log of Real GDP used as proxy for economic activity. GDP in constant LCU is used. Source: Bank of Uganda \& World } \\
\text { Bank }\end{array}$ \\
\hline lnirs & $\begin{array}{l}\text { Log of the interest rate spread; it is the opportunity cost variable, calculated as the difference or spread between deposit } \\
\text { rate and lending rate which depicts the return on domestic non-monetary financial assets relative to domestic assets. A } \\
\text { rise in this spread will make domestic monetary assets more attractive compared to the financial monetary assets. The } \\
\text { reverse is true. The sign on interest rate would depend on the definition of money: narrow money (non-interest bearing } \\
\text { money) would be expected to yield a negative sign on interest rate; broad money may depend on the differential } \\
\text { between interest rate on money and interest rate on alternative financial assets (Kararaach, 2002). Source: Bank of } \\
\text { Uganda \& World Bank }\end{array}$ \\
\hline lninfl & $\begin{array}{l}\text { Log of the inflation rate; it is an opportunity cost variable that measures monetary stability of a country. We compute it } \\
\text { as the change in CPI. A priori, we expect inflation to have a negative impact on the demand for money. Source: Bank of } \\
\text { Uganda \& World Bank. }\end{array}$ \\
\hline lnexch_rate & $\begin{array}{l}\text { Log of the nominal exchange rate measured as the average local currency per US\$. We anticipate either a positive or a } \\
\text { negative coefficient. Source: International financial statistics (IFS) \& Bank of Uganda. }\end{array}$ \\
\hline lnfin_12 & $\begin{array}{l}\text { Log of financial innovation measured as the ratio of narrow money (M1) to broad money (M2). We expect a positive } \\
\text { coefficient sign. }\end{array}$ \\
\hline
\end{tabular}

Table 2. Descriptive statistics

\begin{tabular}{lccccc}
\hline & $(1)$ & $(2)$ & $(3)$ & $(4)$ & $(5)$ \\
& $\mathrm{N}$ & mean & sd & $\min$ & $\max$ \\
\hline lngdp & 32 & 26.13 & 0.600 & 25.15 & 27.09 \\
$\operatorname{lnm} 11$ & 32 & 23.25 & 1.040 & 21.57 & 24.89 \\
lnmd2 & 32 & 23.73 & 1.229 & 21.67 & 25.58 \\
lnfin_12 & 32 & -0.484 & 0.321 & -1.550 & -0.0871 \\
lnexch_rate & 30 & 0.183 & 0.309 & -0.199 & 1.118 \\
lnirs & 32 & 2.206 & 0.901 & -2.485 & 2.722 \\
lninfl & 31 & 2.148 & 1.669 & -2.676 & 5.298 \\
\hline
\end{tabular}

Table 3. Pairwise correlation of main explanatory variables

\begin{tabular}{lccccc}
\hline & lngdp & Infin_12 & Inirs & Inexch_rate & Ininfl \\
\hline lngdp & 1 & & & & \\
Infin_12 & $-0.635^{* * *}$ & 1 & & & \\
lnirs & 0.273 & -0.206 & 1 & 1 & 1 \\
lnexch_rate & $-0.629^{* * *}$ & $0.402^{*}$ & -0.294 & $0.486^{* *}$ & 1 \\
lninfl & -0.210 & 0.318 & -0.271 & & \\
\hline
\end{tabular}

Note. ${ }^{*} p<0.05,{ }^{* *} p<0.01,{ }^{* * *} p<0.001$.

Table 4. Unit root test results

\begin{tabular}{|c|c|c|c|c|c|}
\hline \multirow[t]{2}{*}{ Variables } & \multicolumn{2}{|c|}{ Levels } & \multicolumn{2}{|c|}{ Firs Differences } & \multirow[t]{2}{*}{ Order of Integration } \\
\hline & $\mathrm{ADF}$ & $\mathrm{PP}$ & $\mathrm{ADF}$ & $\mathrm{PP}$ & \\
\hline $\operatorname{lnm} d 1$ & $-0.922(0.9538)$ & $-0.423(0.9862)$ & $-5.226(0.0001)$ & $-7.054(0.0000)$ & $\mathrm{I}(1)$ \\
\hline $\operatorname{lnm} d 2$ & $-1.840(0.6854)$ & $-2.494(0.3310)$ & $-4.121(0.0059)$ & $-7.865(0.0000)$ & $\mathrm{I}(1)$ \\
\hline $\operatorname{lng} d p$ & $-3.556(0.0338)$ & $-5.934(0.0000)$ & & & $\mathrm{I}(0)$ \\
\hline lnfin_12 & $-0.589(0.9795)$ & $0.508(0.9969)$ & $-4.742(0.0006)$ & $-6.032(0.0000)$ & $\mathrm{I}(1)$ \\
\hline lnirs & $-3.609(0.0291)$ & $-3.670(0.0244)$ & & & $\mathrm{I}(0)$ \\
\hline lnexch_rate & $-2.910(0.1589)$ & $-2.853(0.1782)$ & $-7.737(0.0000)$ & $-13.898(0.0000)$ & $\mathrm{I}(1)$ \\
\hline lninfl & $-3.568(0.0327)$ & $-1.792(0.7087)$ & $-4.903(0.0003)$ & $-5.572(0.0000)$ & $\mathrm{I}(1)$ \\
\hline
\end{tabular}

Note. p-values are presented in parenthesis. The critical values are -4.032 , and -3.447 at $1 \%$ and $5 \%$ respectively. 


\section{Results and Discussion}

\subsection{Cointegration Test Results}

As submitted earlier, we test the number of cointegrating relationships among variables using the Bounds testing approach to cointegration. First, we apply the OLS to Equation (4) to test the existence of a cointegrating long run relationship based on the Wald test for the joint significance of the variables. Using the Akaike information criterion (AIC), HQIC and the schwarz bayesian criterion (SBC) lag length criteria tests, the optimal lag length for the regressions is 3 (Table 5). In Table 6, the results from the Pesaran, Shin, and Smith (2001) ARDL Bounds Test of co-integration demonstrate that the null hypothesis of no levels in relationship against its alternative is rejected at the $1 \%$ significance level. The computed F-statistic of 8.713 is greater than the lower critical bound value of 3.47, at $1 \%$ level of significance, thus indicating the existence of a steady-state long-run relationship among the variables.

Table 5. Statistics for selecting the optimal lag order

\begin{tabular}{cccc}
\hline Lag & AIC & HQIC & SBIC \\
\hline 0 & -1.28778 & -1.2005 & -1.0023 \\
1 & -1.41259 & -1.31077 & $-1.07954^{*}$ \\
2 & -1.35277 & -1.23641 & -0.97214 \\
3 & $-1.46069^{*}$ & $-1.32978^{*}$ & -1.03248 \\
\hline
\end{tabular}

Note. *denotes the optimal lag length.

Table 6. ARDL bounds test of co-integration

\begin{tabular}{ccc}
\hline Critical value & Lower Bound Value & Upper Bound Value \\
\hline $1 \%$ & 3.47 & 4.67 \\
$5 \%$ & 3.12 & 4.25 \\
$10 \%$ & 2.75 & 3.79 \\
F-statistic & 3.93 & 5.23 \\
\hline
\end{tabular}

Note. Joint computed F-statistic, 8.713 , significant at $1 \%$.

\subsection{Estimation of Long Run Money Demand Model}

The longrun results presented in Tables 7 and 8 show that financial innovation significantly influences real narrow money demand regardless of whether the inflation rate or exchange rate is accounted for or not but appears to have no effect on real broad money. Specifically, Column (1), Table 7 implies that a $10 \%$ increase in financial innovation would lead to a 9\% decrease in demand for money. When control variables are included, the interpretation remains largely the same. Specifically, increasing financial innovation by $10 \%$ is likely to result into about $10 \%$ increase in the demand for real money balances in terms of narrow money. The result is in line with previous findings in Akinlo (2012), Hye (2014), and, Nampewo and Opolot (2016). We establish later the channels via which financial innovation might play this role. It remains clear however that controlling for the direct effects of these factors does not significantly affect the outcome. Specification (1) presents results without controls whereas Specification (5) shows the results when all control factors identified are included in the model. In column (4), we drop the exchange rate and inflation rate variables, while in specifications (2) and (3) we drop one variable at a time respectively. Unsurprisingly, in all Columns of Table 7, financial innovation appears to play a crucially significant role in explaining money demand in Uganda. 
Table 7. ARDL Long-run determinants money demand - real narrow money

\begin{tabular}{|c|c|c|c|c|c|}
\hline & (1) & $(2)$ & (3) & $(4)$ & (5) \\
\hline \multirow{2}{*}{ L.lnfin_12 } & $0.905^{* * *}$ & $1.105^{* * *}$ & $0.911 * * *$ & $0.787 * *$ & $0.989 * * *$ \\
\hline & {$[0.296]$} & {$[0.234]$} & {$[0.147]$} & [0.377] & [0.133] \\
\hline \multirow{2}{*}{ L.lngdp } & & -0.045 & -0.374 & 0.389 & -0.349 \\
\hline & & [1.353] & {$[0.930]$} & [2.285] & [0.809] \\
\hline \multirow[t]{2}{*}{ L.lnirs } & & -0.137 & -0.102 & -0.277 & -0.067 \\
\hline & & {$[0.106]$} & {$[0.070]$} & [0.235] & [0.057] \\
\hline \multirow{2}{*}{ L.lninfl } & & $-0.152 * * *$ & & & $-0.059 * *$ \\
\hline & & {$[0.052]$} & & & {$[0.027]$} \\
\hline \multirow[t]{2}{*}{ L.lnexch_rate } & & & $-0.622 * * *$ & & $-0.442 * * *$ \\
\hline & & & {$[0.150]$} & & {$[0.134]$} \\
\hline \multirow[t]{2}{*}{ Trend } & $0.056^{* * *}$ & 0.052 & $0.082 * *$ & 0.034 & $0.084 * *$ \\
\hline & {$[0.018]$} & {$[0.033]$} & {$[0.036]$} & [0.043] & {$[0.032]$} \\
\hline
\end{tabular}

Note. Standard errors in brackets; $* * * \mathrm{p}<0.01, * * \mathrm{p}<0.05, * \mathrm{p}<0.1$.

Table 8. ARDL Longrun results - real broad money

\begin{tabular}{|c|c|c|c|c|c|}
\hline & (1) & (2) & (3) & (4) & (5) \\
\hline \multirow[t]{2}{*}{ L.lnfin_12 } & -0.037 & 0.167 & -0.017 & 0.011 & 0.029 \\
\hline & [0.246] & [0.203] & [0.124] & {$[0.342]$} & [0.111] \\
\hline \multirow[t]{2}{*}{ L.lngdp } & & -0.171 & -0.501 & 0.110 & -0.415 \\
\hline & & [1.408] & [0.947] & [2.518] & [0.821] \\
\hline \multirow[t]{2}{*}{ L. $\ln i r s$} & & -0.130 & -0.098 & -0.280 & -0.062 \\
\hline & & [0.109] & [0.071] & {$[0.260]$} & {$[0.058]$} \\
\hline \multirow[t]{2}{*}{ L.lninf } & & $-0.165 * *$ & & & $-0.063 *$ \\
\hline & & {$[0.058]$} & & & {$[0.030]$} \\
\hline \multirow[t]{2}{*}{ L.lnexch_rate } & & & $-0.652 * * *$ & & $-0.445 * * *$ \\
\hline & & & [0.154] & & {$[0.140]$} \\
\hline \multirow[t]{2}{*}{ Trend } & $0.054 * * *$ & 0.054 & $0.084 * *$ & 0.036 & $0.086^{* *}$ \\
\hline & [0.017] & [0.034] & [0.035] & {$[0.043]$} & {$[0.032]$} \\
\hline
\end{tabular}

Note. Standard errors in brackets; $* * * \mathrm{p}<0.01, * * \mathrm{p}<0.05,{ }^{*} \mathrm{p}<0.1$.

Whereas the direct effects of the exchange rate and inflation are respectively negative and significant, we fail to find evidence of the influence of the real income on money demand in the longrun. In column (5), the income elasticity of the demand for money of negative but not significant. The potential for real income to adversely affect money demand thus exists if we are to go by the sign. Likewise the opportunity cost variable proxied by the interest rate spread, exhibits a negative coefficient albeit lacking in significance at any conventional level. On the other hand, an increase in the exchange rate by $10 \%$ is likely to lead to about 4.4 percent increase in the demand for money. By implication, this expected finding suggests that movements in the exchange rate significantly affect the demand for money in Uganda irrespective of whether it is real narrow money or real broad money. Intuitively, we would expect a depreciation of the local currency to result into increases in the demand for money as deposit liabilities of foreign currency increase in value in terms of domestic currency. As argued in Nyamongo and Ndirangu (2013), such a valuation effect is likely to be compounded by the substitution effect, as local residents shift from local currency-denominated deposits to foreign currency denominated deposits with a weakening currency.

In terms of magnitude and significance, the effect of inflation and exchange rate on money demand appear to differ, with the latter demonstrating a coefficient of -0.059 at $10 \%$ level of significance in relation to -0.442 that is significant at $1 \%$ for the former. Similarly, for real broad money it is -0.063 at $10 \%$ statistical level of significance related to -0.445 at $1 \%$ statistical level of significance. Perhaps the impact of inflation has over years been well controlled so much that its impact is neutralized as a result of the bank of Uganda undertaking the inflation lite monetary framework. In any case it is not illogical to argue that an expected rise in inflation increases the cost of holding money. The result is not only in harmony with economic theory but it is also consistent with findings in Nachega (2001). Intuitively, when people anticipate inflation to rise, they would tend to switch to other money 
alternatives such as equity holdings and investment in land and real estate, as these would promise higher rates of returns. Similarly, the exchange rate elasticity of -0.442 (for real narrow money) or -0.445 (for real broad money) indicates that the exchange rate depreciation has negative impact on the demand for money. It can be argued that an increase in expected real depreciation will cause economic agents to substitute domestic currency with foreign currency. That is, as the domestic currency unit depreciates, agents opt against domestic currency to foreign currency or physical assets. Still the result is in agreement with Nabiddo (2005) and Katarikawe and Sebudde (1999) who in their estimation of the money demand model proxied by broad money also found the elasticity of exchange rate to be significantly negative.

One critical observation is that the interest rate channel appears insignificant either in the real narrow money demand or real broad money demand functions. Perhaps this justifies the argument by some scholars that the variable ought to be dropped out of the model since financial assets (other than money balances) in developing countries, Uganda inclusive, are seriously lacking, and consequently limited the choice of domestic asset holders to either money or real goods; hence very little substitutability (Darrat \& Ali-Sowaidi, 2009). It is of little wonder therefore that the alternative opportunity cost variable, the inflation rate, provides significant results. As in the case of real narrow money model, the relevant coefficients on the exchange rate and inflation rate variables are significantly negative confirming the adverse impact of the same on money demand.

\subsection{ARDL Short-Run Results}

In Table 9 we present ARDL short-run results for the money demand function. The error correction term is throughout negative and statistically significant at $1 \%$ level in columns (1), (2), (3) and (5) but 10\% in column (4). This is an indication that there is cointegration and that money demand is apparently stable. The relevant coefficient value of error correction term in specification (5) is -0.575 , which suggests that 57.5 per cent of discrepancy is eliminated in each shrtrun period. By implication, the speed of ajustment would take approximately two years to return to equilibrium. Still in Table 9, the positive effect of financial innovation on money demand is pronouncingly clear. Given that our measure of financial innovation is the ratio of narrow money to broad money, the positive result suggests that people are able to substitute money with other financial assets such as deposits, causing a decline in the ratio of narrow money to broad money. In specification (5), for example, a $10 \%$ increase in fincancial innovation would lead to a $10.6 \%$ increase in demand for real narrow money.

Table 9. ARDL short-run determinants money demand - real narrow money

\begin{tabular}{|c|c|c|c|c|c|}
\hline & $(1)$ & (2) & (3) & (4) & $(5)$ \\
\hline \multirow[t]{2}{*}{$\mathrm{EC}(-1)$} & $-0.417 * * *$ & $-0.381 * * *$ & $-0.564 * * *$ & $-0.289^{*}$ & $-0.575 * * *$ \\
\hline & [0.139] & {$[0.116]$} & {$[0.148]$} & {$[0.145]$} & [0.131] \\
\hline \multirow[t]{2}{*}{$\Delta \operatorname{lnfin}{ }_{-} 12$} & $1.036 * * *$ & $1.085^{* * * *}$ & $1.080 * * *$ & $1.144 * * *$ & $1.060 * * *$ \\
\hline & {$[0.181]$} & {$[0.127]$} & {$[0.126]$} & {$[0.165]$} & {$[0.112]$} \\
\hline \multirow[t]{2}{*}{$\Delta \operatorname{lng} d p$} & & $0.925^{*}$ & $0.781^{*}$ & $1.074 *$ & $0.834 *$ \\
\hline & & {$[0.447]$} & {$[0.452]$} & {$[0.583]$} & {$[0.401]$} \\
\hline \multirow[t]{2}{*}{$\Delta \ln i r s$} & & -0.016 & 0.004 & -0.007 & -0.008 \\
\hline & & {$[0.021]$} & {$[0.021]$} & {$[0.027]$} & [0.019] \\
\hline \multirow[t]{2}{*}{$\Delta \operatorname{lninf}$} & & $-0.039 * * *$ & & & $-0.034 * *$ \\
\hline & & {$[0.013]$} & & & {$[0.013]$} \\
\hline \multirow[t]{2}{*}{ slnexch_ratel } & & & $-0.351 * * *$ & & $-0.254 * * *$ \\
\hline & & & {$[0.085]$} & & {$[0.085]$} \\
\hline Adj. R-squared & 0.530 & 0.793 & 0.795 & 0.646 & 0.839 \\
\hline
\end{tabular}

Note. EC(-1) is the error correction term; Standard errors in brackets; *** $\mathrm{p}<0.01,{ }^{* *} \mathrm{p}<0.05,{ }^{*} \mathrm{p}<0.1$.

On the other hand, it is interesting to observe that in Table 10, we fail to find evidence of the role of financial innovation in real broad money in the short run. Although the relevant coefficient is expectedly positive in Column (5), it lacks significance at any conventional level. This is remains the case whether we control for the macroeconomic variables or not. Nevertheless the finding is consistent with documentations in the previous studies by inter alia Kovanen (2004) and, Sichei and Kamau (2012). Income, measured as real GDP, is here found to exhibit facilitative role in the money demand whereas interest rate spread does not appear to significantly determine real broad money. As observed in the real narrow money model, the exchange rate and inflation rate play a perverse role in real broad money demand significant at $1 \%$ and $5 \%$ respectively. The impact of the latter is however recorded smaller in magnitude relative to that of the former. 
Table 10. ARDL shortrun results - real broad money

\begin{tabular}{|c|c|c|c|c|c|}
\hline & $(1)$ & (2) & (3) & (4) & (5) \\
\hline \multirow{2}{*}{$E C(-1)$} & $-0.404 * * *$ & $-0.376^{* * *}$ & $-0.548 * * *$ & $-0.263^{*}$ & $-0.567 * * *$ \\
\hline & {$[0.132]$} & {$[0.118]$} & {$[0.146]$} & {$[0.143]$} & {$[0.131]$} \\
\hline \multirow[t]{2}{*}{$\Delta \operatorname{lng} d p$} & & $0.909 *$ & 0.748 & $1.037^{*}$ & $0.820^{*}$ \\
\hline & & [0.456] & [0.447] & {$[0.583]$} & [0.403] \\
\hline \multirow[t]{2}{*}{$\Delta \ln f i n_{-} 12$} & -0.015 & 0.063 & -0.009 & 0.003 & 0.016 \\
\hline & [0.099] & [0.074] & {$[0.068]$} & {$[0.090]$} & [0.063] \\
\hline \multirow[t]{2}{*}{$\Delta \ln i r s$} & & -0.016 & 0.004 & -0.007 & -0.009 \\
\hline & & [0.022] & {$[0.021]$} & {$[0.027]$} & [0.019] \\
\hline \multirow[t]{2}{*}{$\Delta \operatorname{lninf}$} & & $-0.041 * *$ & & & $-0.036^{* *}$ \\
\hline & & {$[0.015]$} & & & [0.016] \\
\hline \multirow[t]{2}{*}{$\Delta$ lnexch_ratel } & & & $-0.357 * * *$ & & $-0.252 * * *$ \\
\hline & & & {$[0.084]$} & & {$[0.087]$} \\
\hline Adj. R-squared & 0.185 & 0.630 & 0.598 & 0.364 & 0.681 \\
\hline
\end{tabular}

In either models in Tables 9 and 10, the real income elasticity of money demand exhibits a positive sign through all the specifications. The finding of income elasticity closer to unity, is consistent with the quantity theory of money which postulates that an increase in real income increases the level of transactions, and consequently the demand for real money balances to facilitate the high level of transactions in an economy. Previous studies have documented similar effect (e.g. Nachega, 2001). Note however that the coefficient value on the real income variable, sometimes above 1, say in column (4) would imply that the Ugandan economy is becoming highly monetized due to several structural changes.

The error correction term in Column (5) is negative and highly statistically significant in both Tables 9 and 10. By implication, the relevant respective coefficients of -0.575 and -0.567 further lends credence to the cointegration among the variables under investigation. In essence, the observed feedback coefficient suggests that disequilibria of about 58\% and 57\% respectively are corrected in the current year. In other words, when money demand operates above or below its equilibrium level, the speed of adjustment is about 58\% in Table 8 and $57 \%$ in Table 9 , within the first year to ensure full convergence to its equilibrium level. Overall, the results indicate that in the short run, while change in financial innovation, real income, exchange rate and inflation have significant impact on the demand for narrow money in Uganda, data provides insufficient evidence of the effect of financial innovation on real broad money. One resultant question has to do with the channels via which financial innovation may affect or not affect money demand. We turn to this inquisition by analyzing the interaction terms in equation (4) from both the real narrow money and real broad money perspective.

\subsection{ARDL Results - Interactions}

We present the results with regard to the impact of financial innovation on real narrow money balances in the presence of the traditional macroeconomic drivers of money demand in Tables 11 and 12. While the income channel and the inflation rate channel appear crucial in the influence of financial innovation on real narrow money demand, the exchange rate and interest rate channels are do not significantly affect the linkage both in the longrun and shortrun. The interactive effect of financial innovation is stronger in the income channel at 5\% level of significance, compared to the inflation channel. Specifically, the positive interaction in Column (1) would imply that the higher the real income, the greater the effect of financial innovation on money demands. The observed significant interaction effect rather indicates that the effect of financial innovation on the real narrow money demand depends on the value of real income. Similarly, the impact of financial innovation on real narrow money balances appears to be dependent on the rate of inflation, as demonstrated in Column (4) in Table 10. The negative significant interaction would mean that the effect of the combined action of financial innovation and inflation rate is less than the sum of the individual effects. In other words, the association between financial innovation and money demand in Uganda appear to increase once inflation decreases. We can reasonably state therefore that the effect of financial innovation observed in empirical work and in the current study will get smaller as the rate of inflation gets larger. Alternatively, the effect of inflation on money demand will reduce as financial innovation gets larger. Still in Table 10, column (3), the insignificant interaction effect on the one hand and the significant coefficients of the two main effects (1.621 and -1.077) is equally informative; it implies that while there is a relationship between financial innovation and money demand, and an association between 
exchange rate and real money balances, the exact nature of these relationships is not altered basing on the value of the co-independent variable. In other words, financial innovation and the exchange rate affect the probability of observing the event in the money demand, but the exchange rate channel in this case does not affect the relationship between financial innovation and real money demand. Our interpretation is valid for both the shortrun and longrun as shown in the relevant coefficients in Tables 10 and 11.

On the other hand, the results suggest that while the real income and inflation rate channels are crucial in the financial-innovation-money-demand relationship, for real broad money too, here the relevant interaction coefficient is only significant in the shortrun as evident in column (8), Table 11. Specifically, the total marginal impact of financial innovation on real broad money in the presence of increasing inflation is - 0.031 (i.e. 0.351 $0.187 * 2.042$ ), which is suggestive of the detrimental role of inflation on the nexus between financial innovation and real broad money demand. Note that for real narrow money, the total marginal impact turns out to be 0.949 , a result that points to the increasing demand for narrow money due to changes in financial innovation conditional on the rate of inflation.

Table 11. ARDL long-run determinants money demand - interactions

\begin{tabular}{|c|c|c|c|c|c|c|c|c|}
\hline & \multicolumn{4}{|c|}{ Real narrow money (M1/CPI) } & \multicolumn{4}{|c|}{ Real broad money (M2/CPI) } \\
\hline & $(1)$ & (2) & (3) & (4) & $(5)$ & (6) & (7) & $(8)$ \\
\hline \multirow[t]{2}{*}{ L.lngdp } & 0.084 & -0.257 & 0.264 & 0.263 & 0.055 & -0.24 & 0.264 & -0.083 \\
\hline & {$[0.679]$} & {$[0.923]$} & [1.117] & {$[0.773]$} & {$[0.661]$} & {$[0.878]$} & [1.117] & [0.863] \\
\hline \multirow[t]{2}{*}{ L.lnfin_12 } & $-1.152 * *$ & 3.599 & $1.621 * * *$ & $2.066^{* * *}$ & $-1.432 * *$ & 2.226 & 0.621 & 0.688 \\
\hline & [7.489] & [2.735] & [0.454] & {$[0.555]$} & [7.310] & [2.053] & {$[0.454]$} & [0.428] \\
\hline \multirow[t]{2}{*}{ L.ln irs } & -0.049 & -0.336 & -0.002 & -0.004 & -0.045 & -0.302 & -0.002 & -0.031 \\
\hline & [0.047] & [0.299] & {$[0.044]$} & [0.029] & {$[0.044]$} & {$[0.242]$} & {$[0.044]$} & [0.039] \\
\hline \multirow[t]{2}{*}{ L.lnexch_rate } & -0.108 & $-0.436 * *$ & $-1.077 * *$ & 0.238 & -0.104 & $-0.435^{* * * *}$ & $-1.077 * *$ & -0.08 \\
\hline & [0.169] & {$[0.155]$} & {$[0.478]$} & [0.291] & [0.165] & [0.148] & [0.478] & {$[0.224]$} \\
\hline \multirow[t]{2}{*}{ L.lninf } & -0.033 & $-0.074^{*}$ & -0.066 & $-0.363 * *$ & -0.035 & $-0.070^{*}$ & -0.066 & $-0.268 *$ \\
\hline & {$[0.026]$} & {$[0.039]$} & {$[0.040]$} & [0.153] & {$[0.025]$} & {$[0.034]$} & {$[0.040]$} & [0.128] \\
\hline \multirow[t]{2}{*}{ L.fil2_ $g d p$} & $0.674 * *$ & & & & $0.685^{* *}$ & & & \\
\hline & {$[0.278]$} & & & & {$[0.272]$} & & & \\
\hline \multirow[t]{2}{*}{ L.fil2_irs } & & -1.052 & & & & -0.91 & & \\
\hline & & [1.099] & & & & {$[0.847]$} & & \\
\hline \multirow[t]{2}{*}{ L.fil2_exch } & & & -3.602 & & & & -3.602 & \\
\hline & & & [2.358] & & & & [2.358] & \\
\hline \multirow[t]{2}{*}{ L. fi12_infl } & & & & $-0.547^{*}$ & & & & -0.367 \\
\hline & & & & {$[0.290]$} & & & & [0.225] \\
\hline \multirow[t]{2}{*}{ Trend } & $0.089 * * *$ & $0.074 * *$ & 0.047 & $0.062 *$ & $0.089 * * *$ & $0.075^{* *}$ & 0.047 & $0.066^{*}$ \\
\hline & [0.029] & [0.034] & [0.039] & {$[0.033]$} & {$[0.028]$} & {$[0.033]$} & [0.039] & {$[0.032]$} \\
\hline
\end{tabular}

Note. Standard errors in brackets; *** $\mathrm{p}<0.01, * * \mathrm{p}<0.05, * \mathrm{p}<0.1$.

Table 12. ARDL short-run determinants money demand

\begin{tabular}{|c|c|c|c|c|c|c|c|c|}
\hline & \multicolumn{4}{|c|}{ Real narrow money (M1/CPI) } & \multicolumn{4}{|c|}{ Real broad money (M2/CPI) } \\
\hline & (1) & (2) & (3) & (4) & (5) & (6) & (7) & (8) \\
\hline \multirow[t]{2}{*}{$\Delta l n g d p$} & $1.015^{* *}$ & $0.987 * *$ & $1.009^{* *}$ & $0.994 * *$ & $1.008 * *$ & $0.974 * *$ & $1.009^{* *}$ & $0.914 * *$ \\
\hline & {$[0.371]$} & [0.433] & {$[0.410]$} & [0.382] & {$[0.361]$} & [0.419] & {$[0.410]$} & {$[0.377]$} \\
\hline \multirow[t]{2}{*}{$\Delta \operatorname{lnfin} \_12$} & $-1.422 * *$ & $2.305^{*}$ & $1.000 * * *$ & $1.205^{* * *}$ & $-1.566 * *$ & 1.176 & 0 & $0.351^{*}$ \\
\hline & [4.640] & {$[1.142]$} & [0.109] & {$[0.166]$} & [4.501] & {$[0.971]$} & [0.109] & [0.169] \\
\hline \multirow[t]{2}{*}{$\Delta \ln i r s$} & -0.011 & -0.152 & -0.001 & -0.002 & -0.011 & -0.135 & -0.001 & -0.016 \\
\hline & {$[0.017]$} & {$[0.133]$} & [0.019] & {$[0.017]$} & {$[0.017]$} & [0.107] & [0.019] & {$[0.018]$} \\
\hline \multirow[t]{2}{*}{$\Delta$ lnexch_ratel } & -0.068 & $-0.226 * *$ & -0.179 & 0.139 & -0.065 & $-0.230 * *$ & -0.179 & -0.041 \\
\hline & [0.108] & [0.092] & [0.302] & {$[0.150]$} & [0.105] & {$[0.088]$} & [0.302] & {$[0.120]$} \\
\hline \multirow[t]{2}{*}{$\Delta \operatorname{lninf}$} & -0.021 & $-0.038 * *$ & $-0.030^{*}$ & $-0.103 * *$ & -0.022 & $-0.037 * *$ & $-0.030^{*}$ & $-0.137 * * *$ \\
\hline & [0.016] & [0.017] & [0.014] & [0.044] & [0.015] & {$[0.016]$} & {$[0.014]$} & {$[0.044]$} \\
\hline
\end{tabular}




\begin{tabular}{|c|c|c|c|c|c|c|c|c|}
\hline$\Delta f i 12_{-} g d p$ & $\begin{array}{c}0.426^{* *} \\
{[0.172]}\end{array}$ & & & & $\begin{array}{c}0.430 * * \\
{[0.167]}\end{array}$ & & & \\
\hline$\Delta f i 12 \_i r s$ & & $\begin{array}{c}-0.545 \\
{[0.498]}\end{array}$ & & & & $\begin{array}{c}-0.48 \\
{[0.401]}\end{array}$ & & \\
\hline 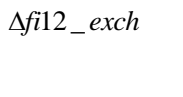 & & & $\begin{array}{c}-0.809 \\
{[0.492]}\end{array}$ & & & & $\begin{array}{c}-0.809 \\
{[0.492]}\end{array}$ & \\
\hline$\Delta f i 12 \_i n f l$ & & & & $\begin{array}{c}-0.126 \\
{[0.091]} \\
\end{array}$ & & & & $\begin{array}{c}-0.187 * * \\
{[0.089]} \\
\end{array}$ \\
\hline$E C(-1)$ & $\begin{array}{c}-0.631 * * * \\
{[0.121]}\end{array}$ & $\begin{array}{c}-0.518^{* * *} \\
{[0.144]}\end{array}$ & $\begin{array}{c}-0.447 * * \\
{[0.189]}\end{array}$ & $\begin{array}{c}-0.583 * * * \\
{[0.125]} \\
\end{array}$ & $\begin{array}{c}-0.627 * * * \\
{[0.118]}\end{array}$ & $\begin{array}{c}-0.528 * * * \\
{[0.134]}\end{array}$ & $\begin{array}{c}-0.447 * * \\
{[0.189]} \\
\end{array}$ & $\begin{array}{c}-0.510^{* * * *} \\
{[0.126]}\end{array}$ \\
\hline Adj. R-squared & 0.87 & 0.834 & 0.833 & 0.864 & 0.754 & 0.688 & 0.551 & 0.723 \\
\hline
\end{tabular}

\subsection{Diagnostic and Stability tests}

The results of the diagnostic tests in Table 13 show that the model is econometrically well specified, particularly as evident from the the Ramsey's RESET test outcome. Also, the reported values from the Breusch-Godfrey Serial Correlation LM test are indicative of no serial correlation in our model. Similarly, the Jacque-Bera test for normality reveals that the model is normally distributed.

Table 13. Diagnostic tests

\begin{tabular}{lcc}
\hline & Coefficient & F-Statistic \\
\hline RESET test & 0.4926 & 0.83 \\
Jacque-Bera test & 0.3118 & 2.331 \\
Breusch-Godfrey LM test & 0.009 & 0.9262 \\
Adj. R-squared & & 0.98 \\
\hline
\end{tabular}

Besides the aforementioned diagonistic tests, we establish the stability of the models. As explained earlier, this is achieved by employing the cumulative sum (CUSUM) and the cumulative sum squares (CUSUMSQ) tests proposed by Durbin et al. (1975). While the former helps to show if the coefficients of regression are changing systematically, the latter helps to determine if the coefficients of the model change suddenly (Bhatti et al., 2006). For stability to hold, the test requires that both the CUSUM and the CUSUMSQ statistics stay within the area between the two critical lines, a condition fulfilled in Figures $1 \& 2$. The null hypothesis of parameter stability in the model is therefore accepted. By implication then, we can conclude that the stability of real money demand function exists over the entire sample period. The results generated from the CUSUM stability test reflects stability of the money demand model in the long run. By implication, it is possible to accurately predict the optimal money demand balances required based on the captured explanatory variables. Our finding is consistent with previous documentations in inter alia Epaphra (2017), Nabiddo (2005) and Nachega (2001).

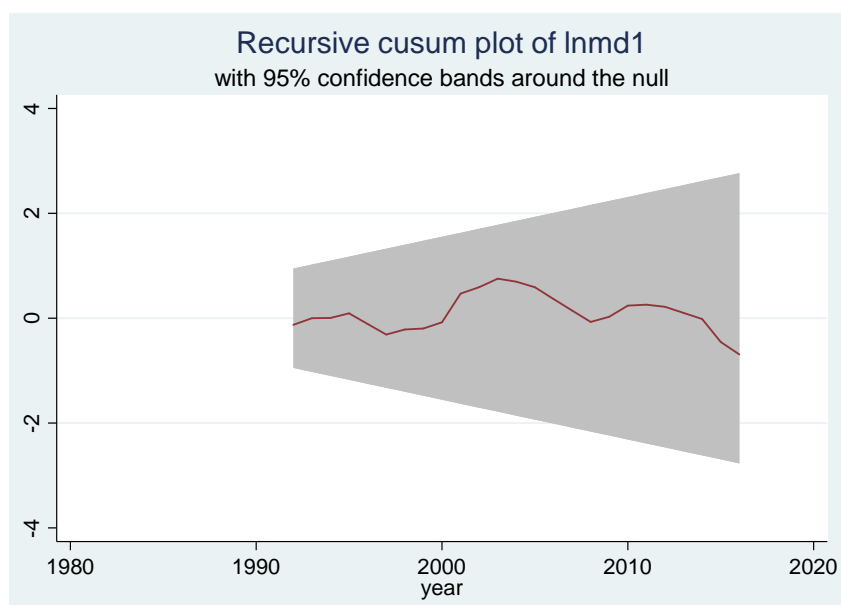

Figure 1. Stability test-CUSUM 


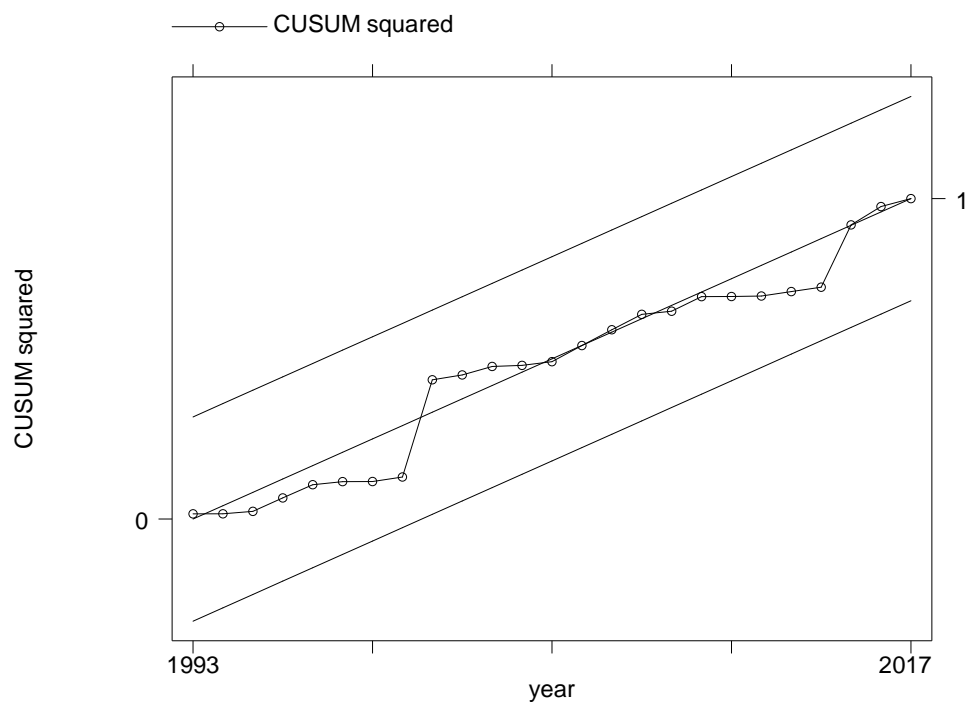

Figure 2. Stability test - CUSUM Squared

\section{Concluding Remarks}

We set out to examine the drivers of real money demand function in Uganda. The most important finding is that there is a positive long run relationship between financial innovation and narrow money both in the shortrun and longrun, but the shortrun elasticity appears greater than the longrun elasticity. This result is robust to the inclusion of other traditonal variables in the model, viz., GDP, intrest rate, inflation and exchange rate. Additionally, the inclusion of interactions in the model leads us to an important conclusion that financial innovation operates most significantly in via the real income as well as the inflation rate channels. There is no evidence that the interest rate channel nor the exchange rate channel matter in influencing the role played by financial innovations in real narrow money demand although the individual contribution of the same to money demand is indismissible. However, going by magnitude, the interest rate spread elasticity is smaller than the exchange rate elasticity, suggesting that the exchange rate channel is potentially stronger than the interest rate channel in the monetary policy transmission mechanism. As such the former would yield a rather more ground impact if applied for monetary policy compared to the latter. The insignificance of the relevant interactions however curtails such conclusions. On the other hand, the indirect impact of the inflation rate channel appears weaker than the real income channel in the longrun,bust also notably smaller in magnitude in both the shortrun and longrun periods. Therefore, in order to influence financial innovations, authorities would probably need to focus more on the real income channel as well as the inflation rate channel. Nevertheless, the study has equally highlighted the significance of the direct contribution of both the exchange rate and inflation rate channels to the demand for real narrow money both in the shortrun and longrun, as well as the insignificance of the direct effect of interest rate spread. Apart from inflation, real interest rate and real GDP, we fail to find evidence of the role of financial innovation on real broad money. This tantamounts to concluding that the extent to which financial inovation influences real money demand depends on the category of money demand under consideration. Nevertheless, the money demand function is found stable over the study period.

The study findings have implications for policy especially with regard to the relevant channels via which financial innovations would better benefit real money demand. Overall, supportive policies that are pro-advancement in the creation and popularizing of the new financial instruments as well as new financial technologies, institutions and markets are strongly recommended for purposes of enhancing pro-growth financial innovations. Policy makers ought to give more attention to the income and inflation rate transmission channels if financial innovations are to be a benefit rather than a risk to money demand stability. The adoption of the inflation lite monetary framework was therefore a right step in the right direction. However, futher research could consider including foreign interest rates into the model to see how they impact on the demand for real money balances. Iyoboyi and Pedro (2014) have attempted to include this variable in the real narrow money demand fucntion for Nigeria, but with no substantial difference in the results relative to models without the variable. A larger sample size compesing the East African countries would attract those interested in the field since financial innovation has become a common phenomena in these countries for the last decade. Clearly, these areas were outside the scope of our analysis, and therefore as subject for future research. 


\section{References}

Adam, C., Kessy, P., Nyella, J. J., \& O'Connell, S. (2010). The Demand for Money in Tanzania. International Growth Centre (IGC) Working Paper, London, UK.

Akinlo, A. E. (2012). Financial Development and the Money velocity in Nigeria: An Empirical Analysis. The Review of Finance and Banking, 4, 97-113

Al-Sowaidi, S. S., \& Darrat, A. F. (2006). Financial Innovations and the Stability of Long-Run Money Demand: Implications for the Conduct of Monetary Policy in the GCC Countries. In ERF, 13th Annual Conference, Kuwait, December 16-18, 2006.

Alvarez, F., \& Lippi, F. (2009). Financial Innovation and the Transactions Demand for Cash. Econometrica, 77(2), 363-402. https://doi.org/10.3982/ECTA7451

Arrau, P., \& Gregorio, J. (1991). Financial innovations and money demand: Theory and empirical implementation. Policy, Research and External Affairs working papers, WPS 585.

Attanasio, O. P., Guiso, L., \& Jappelli, T. (2002). The demand for money, financial innovation, and the welfare cost of inflation: an analysis with household data. Journal of Political Economy, 110(2), 317-351. https://doi.org/10.1086/338743

Bahmani-Oskooee, M., \& Bohl, M. T. (2000). German monetary unification and the stability of the German M3 money demand function. Economics Letters, 203-208. https://doi.org/10.1016/S0165-1765(99)00223-2

Bahmani-Oskooee, M., \& Gelan, A. (2009). How stable is the demand for money in African countries? Journal of Economic Studies, 36(3), 216-235. https://doi.org/10.1108/01443580910983825

Banerjee, A., Dolado, I., Hendry, D., \& Smith, G. (1986). Exploring equilibrium relationship in econometrics through static models: Some Monte-Carlo evidence. Uyfiml lIulletin of Economics and Statistics, 48, 253-277.

Beck, T., \& Hesse, H. (2009). Why Are Interest Rate Spreads so High in Uganda? Journal of Development Economics, 88, 192-204. https://doi.org/10.1016/j.jdeveco.2008.07.004

Ben-Salha, O., \& Jaidi, Z. (2014). Some new evidence on the determinants of money demand in developing countries - A case study of Tunisia. The Journal of Economic Asymmetries, 11, 30-45. https://doi.org/10.1016/j.jeca.2014.06.001

Bhatti, M. I., Al-Shanfari, H., \& Hossain, M. Z. (2006). Econometric analysis of model selection and model testing. Aldershot, Hants, England; Burlington, VT: Ashgate, UK.

Cziraky, D., \& Gillman, M. (2006). Money Demand in an EU Accession Country: A VECM Study of Croatia. Bulletin of Economic Research, 58(2), 73-159. https://doi.org/10.1111/j.0307-3378.2006.00237.x

Darrat A. F., \& Al-Sowaidi, S. S. (2009). Financial progress and the stability of long-run money demand: Implications for the conduct of monetary policy in emerging economies. Review of Financial Economics, 18, 124-131. https://doi.org/10.1016/j.rfe.2009.04.003

Deckle, P., \& Pradhan, M. (1997). Financial Liberalization and Money Demand in ASEAN Countries: Implications for Monetary Policy. IMF Working Paper WP/97/36. https://doi.org/10.5089/9781451845419.001

Dobson, S., \& Ramlogan, C. (2001). Money Demand and Economic Liberalization in a Small Open EconomyTrinidad and Tobago. Open Economies Review. https://doi.org/10.1023/A:1011137624007

Dunne, J. P., \& Kasekende, E. (2016). Financial Innovation and Money Demand: Evidence from Sub-Saharan Africa. Economic Research Southern Africa, ERSA working paper 583.

Durbin, J., Brown, R., \& Evans, J. (1975). Techniques for testing the constancy of regression relationships over time. Journal of the Royal Statistical Society: Series B (Methodological), 37(2), 149-192.

Economic Policy Research Centre, EPRC. (2013). UGANDA 2013 FinScope III SURVEY REPORT FINDINGS: Unlocking Barriers to Financial Inclusion. Makerere University campus, Kampala.

Engle, R. F., \& Granger, C. W. J. (1987). Cointegration and error correction: Representation, estimation and testing. Econometrica, 55, 251-276. https://doi.org/10.2307/1913236

Epaphra, M. (2017). An Econometric Analysis of Demand for Money and its Stability in Tanzania. Turkish $\begin{array}{lllll}\text { Economic } & \text { Review, } & \text { 4(2), } & \text { Retrieved } 192 . & \text { from }\end{array}$ 
http://www.kspjournals.org/index.php/TER/article/view/1314/1344

Fisher, I. (1911). The Purchasing Power of Money: Its Determination and Relation to Credit, Interest and Crisis. New York: Macmillan.

Fredrick, S. M. (2007). The economics of momeny, banking, and financial markets (8th ed.).

Freedman, C., \& Laxton, D. (2009). Why Infl ation Targeting? IMF Working Paper 09/86.

Friedman, M. (1956). The quantity theory of money-a restatement. In:M. Friedman (Ed.), Studies in the Quantity Theory of Money (pp. 3-21). Chicago: University of Chicago Press.

Friedman, M. (1977). Time Perspective in Demand for Money. Scandinavian Journal of Economics, 79(4), 397-416. https://doi.org/10.2307/3439699

Goldfeld, S. M., \& Sichel, D. E. (1990). The Demand for Money. In B. M. Friedman, \& F. H. Hahn (Eds.), Handbook of Monetary Economics (Vol. 1, pp. 300-56). NewYork: North-Holland.

Gujarati, D. (2004). Basic Econometrics (4th ed.). Published in the McGraw-Hill Companies.

Hamori, S. (2008). Empirical Analysis of the Money Demand Function in Sub-Saharan Africa. Economics Bulletin, $15(4), 1-15$.

Handa, J. (2000). Monetary economics. London: Routledge. https://doi.org/10.4324/9780203456910

Hendry, D. (1993). Cointegration, Error Correction, and the Econometric Analysis of Non-Stationary Data. Oxford University Press.

Hendry, D. F. (1987). Econometric methodology; a personal perspective in advances in econometrics. T. Bewley (Ed.), Cambridge University Press, M.A.

Ho, N. W. (2006). Financial Innovation and Its Impact on Central-Bank Policies. Monetary Authority of Macao.

Hye, Q. M. A. (2009). Financial Innovation and Demand for Money in Pakistan. Asian Economic Review, 51(2), 219-228.

Iyoboyi, M., \& Pedro, L. M. (2013). The Demand for Money in Nigeria: Evidence from Bounds Testing Approach. Business and Economics Journal, BEJ-76.

Johansen, S., \& Juselius, K. (1990). Maximum Likelihood Estimation and Inference onCointegration with Application to the Demand for Money. Oxford Bulletin of Economics and Statistics. Oxford University, England.

Judd, J. P., \& Scadding, J. L. (1982). The Search for a Stable Money Demand Function: A Survey of the Post-1973 Literature. Journal of Economic Literature, 20(3), 993-1023.

Kararach, G. (2002). Evidence on the Demand for Money Function in Uganda. UNICEF Zimbabwe Working Paper No. 2002-01. https://doi.org/10.2139/ssrn.379880

Katarikawe, M., \& Sebudde, R. (1999). Is reserve money programme still a useful operating framework for the conduct of monetary policy in Uganda? Bank of Uganda, Staff Papers, 1(1), 1-33.

Keynes, J. M. (1936). The General Theory of Employment, Interest and Money. Cambridge: MacMillan.

Kiptui, M. C. (2014). Some Empirical Evidence on the Stability of Money Demand in Kenya. International Journal of Economics and Financial Issues, 4(4), 849-858.

Kripfganz, S., \& Schneider, D. C. (2016). ardl: Stata module to estimate autoregressive distributed lag models. Stata Conference Chicago, July 29, 2016.

Laurenceson, J., \& Chai, J. C. H. (2003). Financial reforms and economic development in China. Cheltenham, UK, Edward Elgar., 1-28.

Lippi, F., \& Secchi, A. (2009). Technological change and the households' demand for currency. Journal of Monetary Economics, 222-230. https://doi.org/10.1016/j.jmoneco.2008.11.001

Majid, M. Z. A. (2004). Reassessing the Stability of Broad Money Demand in Malaysia. Bank Negara, Malaysia Discussion Papers, Kuala Lumpur.

Mannah-Blankson, T., \& Belyne, F. (2004). The Impact of Financial Innovation on the Demand for Money in Ghana. Bank of Ghana Working Paper (2004).

Maravić, J., \& Palić, M. (2005). Econometric analysis of money demand in Serbia. Belgrade: National Bank of Serbia Research Department. 
Mark, N. C., \& Sul, D. (2003). Cointegration Vector Estimation by Panel DOLS and Long-run Money Demand. Oxford Bulletin of Economics and Statistics, 65(5). https://doi.org/10.1111/j.1468-0084.2003.00066.x

Misati, R. N., Nyamongo, E. M., \& Kamau, A. W. (2011). Interest rate pass-through in Kenya. International Journal of Development Issues, 10(2), 170-182. https://doi.org/10.1108/14468951111149104

Mohamed, B. M. (2013). Assessing the Short and Long-run Real Effects of Public External Debt: The Case of Tunisia. African Development Review, 25(4), 587-606. https://doi.org/10.1111/1467-8268.12054

Muhammad, A., Muhammad, I. C., \& Amjad, A. (2012). Determinants of Money demand in Pakistan: The disaggregated expenditure approach. National College of Business Administration and Economics (NCBA\&E), Lahore, Pakistan, Research Foundation for Humanity (RFH).

Mwega, F. (2011). The competitiveness and efficiency of the financial services sector in Africa: A case study of Kenya. African Development Review, 23(1), 44-59.

Nabiddo, W. (2005). Analysis of the determinants of money demand in Uganda (1986-2003). Dissertation thesis, Unpublished.

Nachega, J. C. (2001). Financial liberalization, money demand and inflation in Uganda. International Monetary Fund Working Paper 01/118.

Nagayasu, J. (2012). Financial Innovation and Regional Money. Applied Economics, 4617-4629. https://doi.org/10.1080/00036846.2011.593500

Nampewo, D., \& Opolot, J. (2016). Financial innovations and Money Velocity in Uganda. Bank of Uganda Working Paper Series, Working Paper No. 05/2016, October 2016, Kampala. https://www.bou.or.ug/

Nchor, D., \& Adamec, V. (2016). Investigating the Stability of Money Demand in Ghana. Procedia - Social and Behavioral Sciences, 220, 288-293. https://doi.org/10.1016/j.sbspro.2016.05.501

Ndirangu, L., \& Nyamongo, E. M. (2015). Financial innovations and Their Implications for Monetary Policy. Journal of African Economies, 24(AERC Supplement 1), i46-i71. https://doi.org/10.1093/jae/eju029

Nyamongo, E., \& Ndirangu, L. (2013). Financial innovation and monetary policy in Kenya. Draft Paper for Comments Submitted to the African Economic Research Consortium (AERC) Biannual Research Workshop on Financial Inclusion and Innovation in Africa, 1-5 December 2013.

Ollama, C. (2017). The determinants and stability of money demand in Uganda. Unpublished Research Paper, Makerere University.

Omotor, G. D. (2009) . Money Demand and Foreign Exchange Risk for Nigeria:A Cointegration Analysis using ARDL Test. IIUM Journal of Economics and Management, 18(1), 45-72.

Ozturk, I., \& Acaravci, A. (2008). The Demand for Money in Transition Economies. Journal for Economic Forecasting, Institute for Economic Forecasting, 5(2), 35-43.

Payne, E. J. (2003). Post stabilization estimates of money demand in Croatia: Error correction model using the

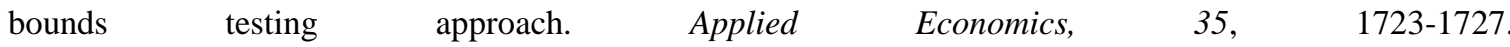
https://doi.org/10.1080/0003684032000152871

Pesaran, M. H., Shin, Y., \& Smith, R. J. (2001). Bounds testing approaches to the analysis of level relationships. Journal of Applied Econometrics, 16, 289-326. https://doi.org/10.1002/jae.616

Phillips, P., \& Perron, P. (1988). Testing for Unit root in Time Series Regression. Biometrika, 335-346. https://doi.org/10.1093/biomet/75.2.335

Pigou, A. C. (1917). The value of money. The Quarterly Journal of Economics, 32(1), 38-65. https://doi.org/10.2307/1885078

Rao, B. B., \& Kumar, S. (2009). A panel data approach to the demand for money and the effects of financial reforms in the Asian countries. Economic Modelling, 26, 1012-1017. https://doi.org/10.1016/j.econmod.2009.03.008

Salisu, A., Ademuyiwa, I., \& Fatai, B. (2013). Modelling the Money Demand in Sub-Saharan Africa (SSA). Economics Bulletin, 33(1).

Sichei, M., \& Kamau, A. (2012). Demand for money: Implications for the conduct of monetary policy in Kenya. International Journal of Economics and Finance, 4(8), 72-82. https://doi.org/10.5539/ijef.v4n8p72

Solans, E. D. (2003). Financial innovation and monetary policy. Speech delivered at the 38th SEACEN Governors 
Conference and 22nd Meeting of the SEACEN Board of Governors on "Structural Change and Growth Prospects in Asia - Challenges to Central Banking," Manila, 13 February 2003.

Sriram, S. S. (1999). Demand for M2 in an emerging-market economy: An error-correction model for Malaysia. International Monetary Fund, WP/99/173, 1-49. https://doi. 10.5089/9781451858617.001

Sriram, S. S. (2001). A Survey of Recent Empirical Money Demand Studies. IMF Staff Papers, 47(3),. 334-365. Retrieved from http://www.jstor.org/stable/3867652

Sriram, S. S. (2009). The Gambia:Demand for Broad Money and its Implications for Monetary Policy Conduct. IMF Working Paper.WP/09/192. https://doi.org/10.5089/9781451873399.001

Suliman, Z., \& Dafaalla, H. A. (2011). An econometric analysis of money demand function in Sudan, 1960-2010. Journal of Economics and International Finance, 3(16), 793-800.

Walsh, C. E. (2010). Monetary Theory and Policy (3rd ed.). Cambridge, MA: MIT Press.

\section{Notes}

Note 1 . The most commonly used measures are gross national product (GNP), gross domestic product GDP) and net national product (NNP). Recent empirical work has however focused on other scale variables involving more comprehensive measures of transactions and the division of transactions into different components on the grounds that not all transactions are equally "money intensive". However this notwithstanding, Goldfeld and Daniel (1990) argue that there is no firm evidence to the effect that the categorization of GNP into various components leads to an improvement in the behavior of the money demand function.

Note 2. See Pesaran, Shin, and Smith (2001) for details.

\section{Copyrights}

Copyright for this article is retained by the author(s), with first publication rights granted to the journal.

This is an open-access article distributed under the terms and conditions of the Creative Commons Attribution license (http://creativecommons.org/licenses/by/4.0/). 